\title{
Historical record of carbonaceous particle concentrations from a European high-alpine glacier (Colle Gnifetti, Switzerland)
}

\author{
V. M. H. Lavanchy ${ }^{1}$ and H. W. Gäggeler ${ }^{1}$ \\ Department of Chemistry and Biochemistry, University of Bern, Bern, Switzerland \\ U. Schotterer, ${ }^{2}$ M. Schwikowski, and U. Baltensperger \\ Paul Scherrer Institute, Villigen, Switzerland
}

\begin{abstract}
Historical records of the concentrations of black carbon (BC) and elemental carbon (EC), as well as of water insoluble organic carbon (OC) and total carbon (TC) covering the time period $\sim 1755-1975$ are presented. Concentrations were obtained from an ice core of a European high-alpine glacier, using an optical and a thermal method. Concentrations were found to vary between 7 and $128 \mu \mathrm{g} \mathrm{L}^{-1}$ for $\mathrm{BC}$, between 5 and $130 \mu \mathrm{g} \mathrm{L}^{-1}$ for EC, between 53 and $484 \mu \mathrm{g} \mathrm{L}^{-1}$ for OC, and between 66 and $614 \mu \mathrm{g} \mathrm{L}^{-1}$ for TC. From preindustrial (1755-1890) to modern times (1950-1975) BC, EC, OC, and TC concentrations increased by a factor of 3.7, 3.0, 2.5, and 2.6, respectively. The sum of $\mathrm{BC}$ emissions of Germany, France, Switzerland, and Italy, calculated from fossil fuel consumption, and the EC concentration record correlate well $\left(R^{2}=0.56\right)$ for the time period from 1890 to 1975; this indicates that the ice core record reflects the emissions of western Europe. High pre-1860 concentrations indicate that by that time BC emissions to the atmosphere were already significant.
\end{abstract}

\section{Introduction}

Carbonaceous particles from combustion processes alter the radiation balance by absorbing and scattering light (direct effect) and by acting as cloud condensation nuclei (indirect effect) and may thus influence the climate [Intergovernmental Panel on Climate Change, 1995]. These particles have a mean atmospheric residence time of about 1 week [Ogren and Charlson, 1983]. Therefore their spatial distribution is highly inhomogeneous and strongly correlated to their sources. Over $90 \%$ of total fossil fuel is combusted at midlatitudes [Cooke and Wilson, 1996]. Biomass burning is the most important source in tropical regions, in savannas, and in boreal latitudes [Liousse et al., 1996]. Carbonaceous aerosols are composed of three main fractions: organic carbon (OC), black carbon (BC) (or elemental carbon (EC)), as well as inorganic carbon (mainly carbonates). The black carbon fraction is strongly light absorbing and resistant to oxidation at temperatures below about $400^{\circ} \mathrm{C}$. It has a polymeric structure resembling the structure of graphitic carbon but with chemical functional groups, so that this fraction has different properties compared to pure graphitic or elemental carbon [Penner and Novakov, 1996]. The separation may be performed thermally, optically, or by solvent extraction [Hansen et al., 1984; Cachier et al., 1989; Petzold and Niessner, 1995]. EC and BC define the same fraction of the carbonaceous aerosol but have a slightly different thermal, optical, and chemical behavior in most cases [Cachier, 1998]. These properties depend on the sources and atmospheric age of carbonaceous aerosols and are responsible for the high degree of complexity of their analysis. Depending on the separation tech-

\footnotetext{
${ }^{1}$ Also at Paul Scherrer Institute, Villigen, Switzerland.

${ }^{2}$ Also at Physics Institute, University of Bern, Bern, Switzerland.

Copyright 1999 by the American Geophysical Unıon.

Paper number 1999JD900408.

0148-0227/99/1999JD900408\$09.00
}

nique, the resulting fractions may be different. In the following, $\mathrm{BC}$ and $\mathrm{EC}$ always denote optically and thermally determined values, respectively. Total carbon (TC) is defined as the sum of EC and OC.

Cold glaciers and polar ice sheets are of interest as archives of the chemical composition of the atmosphere, as atmospheric constituents are deposited by wet and dry deposition and are accumulated in the ice [Wagenbach, 1989]. Polar ice core records have yielded long-term information about the changes of chemical and physical constituents of the atmosphere and reflect global emissions. From these ice core records the evolution of Earth's climate and the historic atmospheric composition over several hundred thousand years have been studied (e.g., see Hammer et al., [1997] and papers of the same issue). In contrast, high-alpine glaciers usually cover timescales of several hundred years because of their higher accumulation rates and their relatively small volumes. They are situated close to anthropogenic activity and are therefore assumed to represent the regional history of emissions, especially of species with short lifetimes such as aerosol particles.

Despite the climatic relevance of carbonaceous particles, historical records from ice cores are scarce [Cachier and Pertuisot, 1994; Chýlek et al., 1992], and none are available representing the history of the European source region. This study presents the first historic record of carbonaceous particle deposition over the last 200 years obtained from an alpine ice core, using an optical and a thermal method. Furthermore, we estimated emissions of carbonaceous aerosols from data of historical coal and petroleum consumption over the last 150 years for different European countries and compared them with our records.

\section{Experimental}

2.1. Ice Core Recovery and Sample Preparation

The investigated ice core was drilled close to the bedrock in 1982 on the glacier saddle Colle Gnifetti, Monte Rosa massif 


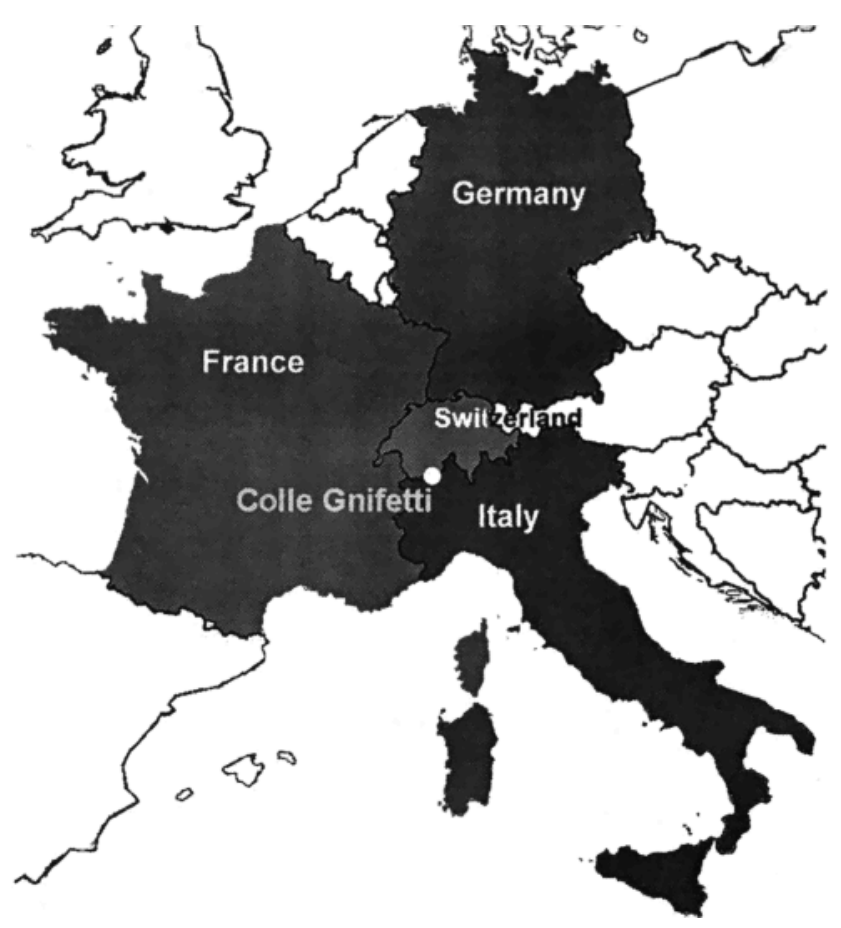

Figure 1. Map of central Europe. The circle shows the drilling site of the ice core.

(4450 $\mathrm{m}$ above sea level (asl), Switzerland (Figure 1). This ice core was $109 \mathrm{~m}$ long and $7.5 \mathrm{~cm}$ in diameter and was sealed in polyethylene bags in sections of 0.5 - to $0.9-\mathrm{m}$ length at the site. More details about glaciochemical studies at this site can be found elsewhere [Oeschger et al., 1977; Haeberli et al., 1983; Schotterer et al., 1985; Wagenbach, 1989; Döscher et al., 1995, 1996]. Dating of the ice core was performed using stratigraphic markers such as Saharan dust events, the atomic bomb horizon in 1963, and identified volcanic eruptions. The resulting timescale was corroborated by continuous measurements of ${ }^{210} \mathrm{~Pb}$ and by a simplified three-dimensional ice flow model [Döscher et al., 1996]. For the time period 1883-1982 the uncertainty of dating is $\sim 2$ years, and for 1756-1882 the uncertainty of dating is $\sim 5$ years [Schwikowski et al., 1999].

Several studies have already been performed on this ice core [Döscher et al., 1995, 1996; Döring, 1999]. Since BC measurements need rather large amounts of ice, a continuous measurement of BC was not possible. Altogether, 54 ice section samples each consisting of up to six subsamples were analyzed. Data shown in this paper are averages of $50-\mathrm{cm}$ sections and represent $37 \%$ of the ice core for the time period $1755-1982$. The most recent sample (1968) covers a time period of 0.8 years, while the oldest sample (1759) covers a time period of 3.5 years. All samples were prepared in a cold room $\left(-20^{\circ} \mathrm{C}\right)$ in a class-100 clean bench. The outermost layer of approximately $0.5-\mathrm{cm}$ thickness was removed by chiseling with a scalpel. A second layer was chiseled from about 100 subsamples and collected for our measurements, while the inner part of the ice core was used for the analysis of heavy metals as described elsewhere [Döring, 1999]. For the other samples the outer layer was removed and the entire inner part of the ice core was used.

Samples (typically $80-200 \mathrm{~g}$ ) were stored in precleaned polyethylene containers and allowed to melt at room temperature. Occasional shaking of the containers resulted in a better mix- ing of the samples thus favoring a faster melting of the ice. Melting time was always less than 4 hours. Immediately after melting, the samples were weighed and then filtered through quartz fiber filters (Tissuequartz QAO 2500, Pall). The circular filters were $15 \mathrm{~mm}$ in diameter and were preheated for 2 hours in a tubular oven at $800^{\circ} \mathrm{C}$. Filtration was performed using a glass unit and resulted in a circular spot of $8 \mathrm{~mm}$ in diameter. The containers were rinsed twice with approximately $10 \mathrm{~mL}$ pure water (MilliQ, $18 \mathrm{M} \Omega$ ) to ensure complete transfer of the carbonaceous particles to the filter. Filtration efficiency was tested gravimetically using suspensions of commercial soot samples (FW2, Degussa) and was found to be $95 \%$. This value is in good agreement with literature data [Cachier and Pertuisot, 1994; Chýlek and Srivastava, 1987].

\subsection{Optical and Thermal Methods}

Figure 2 shows the optical apparatus for filter sample analysis used in this work. This device is a modified version of the aethalometer [Hansen et al., 1984]. The attenuation of light transmitted through a sample is measured by a photodiode. Direct illumination of the filter by the lamp is avoided (see Figure 2). The inner surface of the lamp housing was white thus enhancing the reflection of light from the wall. A reproducible filter positioning was ensured by placing the sample in a slide. To compensate for the variability of the light beam, transmission through a reference filter was measured simultaneously. The attenuation (ATN) of the light beam intensity is defined as

$$
\mathrm{ATN}=\ln \left(I_{0} / I\right) 100 \%,
$$

where $I_{0}$ is the measured light transmission through a reference filter and $I$ is the measured light transmission through the sample. The experimental error originates from inhomogenities of the filter material and of the particle deposition on the filter. In order to minimize the first error, the ATN of every precleaned filter was measured and used as a filter blank in the calculation. To minimize the second error, the ATN was measured 3 times, while rotating the filter between the measurements. The light slot was $6 \mathrm{~mm}$ in diameter.

ATN can be converted into an amount of black carbon BC (micrograms) using

$$
\mathrm{BC}=\frac{\mathrm{ATN}}{\alpha_{\mathrm{API}}} \frac{A_{s}^{2}}{A_{L}},
$$

where $\alpha_{\text {API }}$ is the instrumental absorption efficiency $\left[\mathrm{m}^{2} \mathrm{~g}^{-1}\right]$ of black carbon aerosol particles deposited on the filter, $A_{S}$

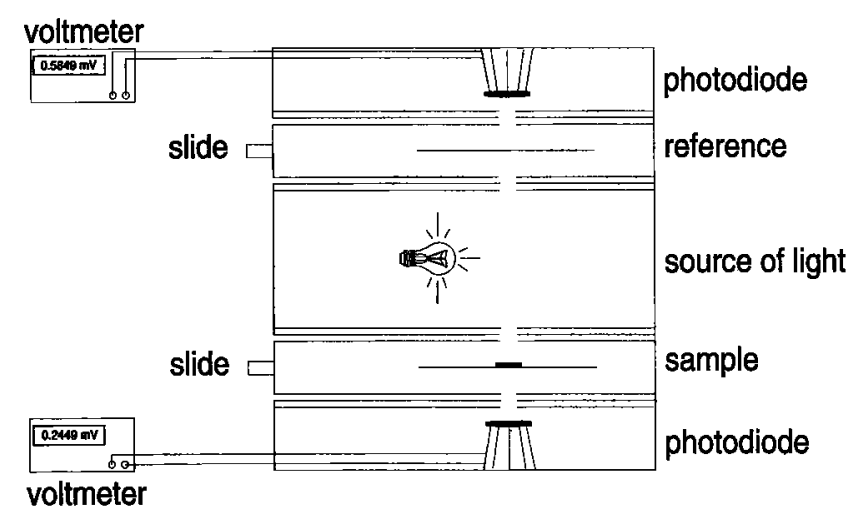

Figure 2. Schematic of the optical apparatus. 
$\left(0.50 \mathrm{~cm}^{2}\right)$ and $A_{L}\left(0.28 \mathrm{~cm}^{2}\right)$ are the surface areas of the sample spot and the filter illuminated by the light source, respectively. The calibration factor $\alpha_{\text {API }}$ has to be determined independently, using for example, a thermal and an optical measurement of the same sample. Several studies have shown that for different sites and for different seasons $\alpha_{\mathrm{API}}$ may vary considerably [Liousse et al., 1993; Petzold et al., 1997]. This topic will be discussed in detail in section 3.3.

Filter blanks were determined by filtering $20 \mathrm{~mL}$ pure water (MilliQ, $18 \mathrm{M} \Omega$ ) and were equivalent to $-0.04 \pm 0.05 \mu \mathrm{g} \mathrm{BC}$ using an $\alpha_{\text {API }}$ value of $9.3 \mathrm{~m}^{2} \mathrm{~g}^{-1}$, as discussed below. Even though this blank value is not significantly different from zero, it may reflect changes in the filter material due to the filtering and analysis procedure. The detection limit, defined as 3 times the filter blank error, was hence $0.14 \mu \mathrm{g} \mathrm{BC}$.

The thermal measurement used in this study is based on a thermal separation between OC and EC by a two-step combustion procedure [Cachier et al., 1989]. The apparatus consists of a combustion unit, composed of two ovens in series, followed by a catalyst oven to ensure total oxidation of the combustion products and a total organic carbon analyzer (TOC700, O.I. Analytical), which accumulates the $\mathrm{CO}_{2}$ produced during the combustion and measures it with a nondispersive infrared detector at the end of a combustion step [Lavanchy et al., 1999]. This setup allows the measurement of the OC and EC contents of the same sample. In the first combustion step, OC was analyzed by oxidation in pure oxygen at a temperature of $340^{\circ} \mathrm{C}$ during $42 \mathrm{~min}$, based on a procedure of Cachier et al. [1989]. To minimize charring, a flash heating (within less than $1 \mathrm{~min}$ ) ensured a rapid heating to this temperature. The remaining carbon, defined as $\mathrm{EC}$, was oxidized at $650^{\circ} \mathrm{C}$. The method was optimized using aliquots of ambient aerosol samples for different precombustion temperatures and duration [Lavanchy et al., 1999]. Possible pyrolitic conversion of OC to EC (charring) and possible loss of EC during the precombustion step are error sources of the thermal separation, caused by the variable chemical and physical properties of both compounds. As a consequence, the EC to OC ratio depends on the efficiency of the thermal separation. In contrast, the TC data have a higher accuracy, since TC is not influenced by this problem [Countess, 1990].

Combustion of carbonates may result in a positive EC artifact during the thermal measurements. The presence of carbonates in ice core samples is mainly due to $\mathrm{CaCO}_{3}$ which in the Alps is often associated with Saharan dust events [Maupetit and Delmas, 1994; Wagenbach et al., 1996]. Maupetit et al. [1995] found a mean $\mathrm{HCO}_{3}^{-}$concentration of $22.1 \mu \mathrm{eq} \mathrm{L}^{-1}$ (corresponding to $1.35 \mathrm{mg} \mathrm{L}^{-1} \mathrm{HCO}_{3}^{-}$) in a different ice core drilled at the Colle Gnifetti. At the EC combustion temperature of $650^{\circ} \mathrm{C}$, dissociation of carbonates, for example, $\mathrm{CaCO}_{3}$, may be neglected [Petzold and Niessner, 1995]. Nevertheless, to avoid possible positive EC artifacts, carbonates were removed prior to thermal analysis by pipetting $50 \mu \mathrm{L} 0.1-M \mathrm{HCl} 3$ times onto the sample spot.

The detection limits of EC and OC are dominated by the variability of the blank loads of the precleaned filters, which were $1.74 \pm 0.60 \mu \mathrm{g} \mathrm{C}$ for $\mathrm{OC}$ and $0.38 \pm 0.47 \mu \mathrm{g} \mathrm{C}$ for $\mathrm{EC}$. The detection limits were thus $1.81 \mu \mathrm{g} \mathrm{C}$ for $\mathrm{OC}$ and $1.42 \mu \mathrm{g}$ $\mathrm{C}$ for $\mathrm{EC}$, the latter being 3 times higher than the detection limit of the optical apparatus. All analyses were performed using both methods, since both methods have their specific advantages and disadvantages. Note that with the described procedure only the water insoluble fraction of organic carbon is determined in contrast to the analysis of aerosol samples.

\subsection{Analysis Procedure}

The light attenuation of the filter samples was measured 3 times. $\mathrm{ATN}_{0}$ was defined as the attenuation of the precleaned filter prior to sample filtration. The attenuation measured after the filtration was denoted $\mathrm{ATN}_{s}$ and resulted from the attenuation by black carbon and mineral particles. After thermal analysis, that is the determination of $\mathrm{OC}$ and $\mathrm{EC}$, when the carbon content of the filter had been removed, ATN $_{E}$ was measured to correct $\mathrm{ATN}_{S}$ for the contribution of mineral dust and the filter blank. This correction turned out to be important since the mineral particle content of ice core samples is several orders of magnitude higher than the black carbon content. Even though $\alpha_{\text {API }}$ of desert dust is about a factor of 100 smaller than $\alpha_{\mathrm{API}}$ of BC [Hansen et al., 1993], the contribution to the attenuation by mineral particles may still be significant. The attenuation due to black carbon $\left(\mathrm{ATN}_{\mathrm{BC}}\right)$ is then

$$
\mathrm{ATN}_{\mathrm{BC}}=\mathrm{ATN}_{s}-\mathrm{ATN}_{E},
$$

and the attenuation due to mineral particles $\left(\mathrm{ATN}_{\mathrm{MP}}\right)$ is

$$
\mathrm{ATN}_{\mathrm{MP}}=\mathrm{ATN}_{E}-\mathrm{ATN}_{0} \text {. }
$$

As discussed in section 2.2, the experimental error of the ATN measurement mainly results from filter inhomogeneity. This error averages to $2.6 \%$, and thus $\mathrm{ATN}_{\mathrm{MP}}$ and $\mathrm{ATN}_{\mathrm{BC}}$ have an uncertainty of $3.7 \%$.

\section{Results and Discussion}

\subsection{Attenuation of the Ice Core Samples}

$\mathrm{ATN}_{\mathrm{BC}}$ and $\mathrm{ATN}_{\mathrm{MP}}$ were determined for each sample according to (3) and (4) and normalized to the sample volume. The values for the time period 1755 to 1975 are shown in Figure 3. It can be seen that the total attenuation increased after about 1890 and that this increase is caused by higher values of $A T N_{B C}$. ATN ${ }_{M P}$ does not show a significant trend, indicating that $\mathrm{BC}$ and mineral particles have different sources. This is consistent with the finding for Ca concentrations which do not exhibit a trend either [Schwikowski et al., 1999].

$\mathrm{ATN}_{\mathrm{MP}}$ accounts for $13 \%$ of the total attenuation, on average, with maximum and minimum values of $30 \%$ and $3 \%$, respectively. Concentrations of $\mathrm{Fe}, \mathrm{Mn}$, and $\mathrm{Ti}$ determined in the same samples by inductively coupled plasma optical emission spectrometry after thermal analysis showed a good correlation with $\mathrm{ATN}_{\mathrm{MP}}\left(R^{2}=0.71, R^{2}=0.72, R^{2}=0.78\right.$, respectively, and $N=53$ ). Fe was the most abundant of these elements (93\%), and the red-brown color of many samples was attributed to hematite $\left(\mathrm{Fe}_{2} \mathrm{O}_{3}\right)$ [Schütz, 1989]. $\mathrm{Fe}_{2} \mathrm{O}_{3}$ is, besides black carbon, one of the few aerosol components that absorbs visible light. Assuming that all $\mathrm{Fe}$ consisted of $\mathrm{Fe}_{2} \mathrm{O}_{3}$ and that $\mathrm{Fe}_{2} \mathrm{O}_{3}$ accounted for $100 \%$ of $\mathrm{ATN}_{\mathrm{MP}}$ and using the measured $\mathrm{Fe}$ concentrations, we derived an instrumental absorption efficiency for $\mathrm{Fe}_{2} \mathrm{O}_{3}$ of $0.13 \pm 0.02 \mathrm{~m}^{2} \mathrm{~g}^{-1}$. When using quartz fiber filters in the optical apparatus, the efficiency of the particles is believed to be enhanced by a factor of about 1.9 because of multiple scattering [Bodhaine, 1995]. Using this factor, an absorption efficiency for suspended $\mathrm{Fe}_{2} \mathrm{O}_{3}$ particles of $0.07 \mathrm{~m}^{2} \mathrm{~g}^{-1}$ is obtained. Given that $\mathrm{Fe}_{2} \mathrm{O}_{3}$ amounts to about $6 \%$ of desert dust [Tomadin et al., 1989], this value compares with the reported absorption efficiency for desert dust ranging 


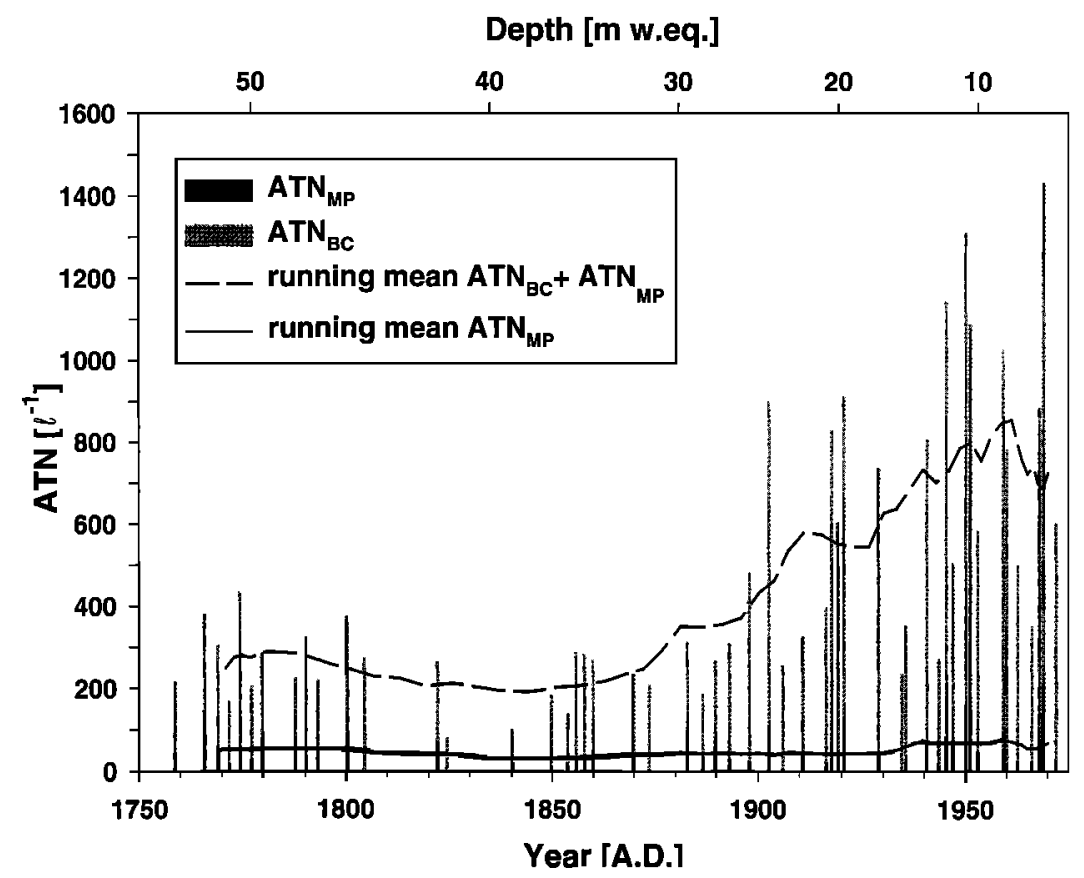

Figure 3. Stacked bar graph of the contribution of black carbon $(B C)\left(A T N_{B C}\right)$ and of mineral particles $\left(A T N_{M P}\right.$ ) to the total attenuation. The sums of $\mathrm{ATN}_{\mathrm{BC}}$ and $\mathrm{ATN}_{\mathrm{MP}}$ (dashed line) and $A T N_{M P}$ (solid line) are shown as a running mean over three samples. Both a timescale and a depth scale in meter water equivalents are given.

between 0.005 and $0.07 \mathrm{~m}^{2} \mathrm{~g}^{-1}$ [Pinnick et al., 1993]. Thus it is reasonable to assume that $A T N_{M P}$ stems completely from $\mathrm{Fe}_{2} \mathrm{O}_{3}$.

\subsection{BC, EC, OC, and TC Concentrations in the Ice Core}

As shown in (2), the $\mathrm{BC}$ values depend on the instrumental calibration factor $\alpha_{\text {API }}$. The range of literature values for aerosol samples obtained with aethalometers is between 4 and 20 $\mathrm{m}^{2} \mathrm{~g}^{-1}$ [Liousse et al., 1993; Petzold et al., 1997]. The high variability is attributed to changes in origin and in physical and chemical properties of the carbonaceous aerosols [Liousse et al., 1993]. To avoid large errors, a specific calibration is required, for example, analyzing the same aerosol sample with an optical and a thermal method.

In the following experiments we used a calibration performed with aerosol sampled by an aethalometer at the highalpine site Jungfraujoch (Switzerland, $3454 \mathrm{~m}$ asl). The mean value over a 2-year sampling period yielded $9.3 \pm 0.4 \mathrm{~m}^{2} \mathrm{~g}^{-1}$ [Lavanchy et al., 1999]. This calibration was considered to be representative of high-alpine aerosol samples and was assumed to be appropriate for snow samples.

Figure 4 shows the measured concentrations of $\mathrm{BC}, \mathrm{EC}, \mathrm{OC}$, and $\mathrm{TC}$ in the ice core samples along with 10-year averages for the time period 1755 to 1975 . It can be seen that for the time period 1800-1850 the 10-year averages partly consist of only one sample. However, these samples also represent at least 2 years. Large fluctuations in concentrations of 1 order of magnitude are observed in all four records. The concentrations varied between 7 and $128 \mu \mathrm{g} \mathrm{L}^{-1}$ for $\mathrm{BC}$, between 5 and 130 $\mu \mathrm{g} \mathrm{L}^{-1}$ for EC, between 53 and $484 \mu \mathrm{g} \mathrm{L}^{-1}$ for OC, and between 66 and $614 \mu \mathrm{g} \mathrm{L}^{-1}$ for TC. The higher variability in the more recent samples is at least partly due to the shorter time averages and is the result of different efficiencies of vertical transport in summer and winter, which is the main process bringing polluted air from the planetary boundary layer (PBL) to high altitudes [Baltensperger et al., 1997; Lugauer et al., 1998]. Correlation $R^{2}$ between the various parameters is generally high: 0.77 (OC-EC), 0.47 (OC-BC), 0.98 (OC-TC), 0.84 (TC$\mathrm{EC}), 0.53$ (TC-BC), and 0.81 (BC-EC).

The $\mathrm{BC}, \mathrm{EC}, \mathrm{OC}$, and $\mathrm{TC}$ concentrations start to increase after 1890 . Box plots in Figure 5 show the average concentrations, the minimum and maximum as well as the $95 \mathrm{th}, 75 \mathrm{th}$, 50th, 25th, and 5th percentiles during the preindustrialized period (1755-1890), the beginning of industrialization in Switzerland until the end of the Second World War (1890-1950), and modern times (1950-1975). It can be seen that on average the $\mathrm{BC}, \mathrm{EC}, \mathrm{OC}$, and TC concentrations increase from the first to the last time period by factors of 3.7, 3.0, 2.5, and 2.6, respectively. This increase is attributed to enhanced anthropogenic emissions and can be compared to the increase of sulfate concentrations reported for the same ice core, beginning in 1890. The sulfate concentration increased by a factor of 5.8 [Doscher et al., 1995] between the periods 1850-1880 and 1965-1981. For the period 1890-1975, sulfate and TC concentrations exhibit a correlation coefficient $R^{2}=0.43$, reflecting the fact that both species have a common dominating source, that is, combustion. Before 1890 the correlation coefficient between the two species is $R^{2}=0.02$.

Compared to the EC and TC concentration records of the Greenland EUROCORE ice core [Cachier and Pertuisot, 1994], the measured EC and TC concentrations are higher by a factor of 10 to 20 . This difference in concentration is attributed to the proximity of the Colle Gnifetti ice core to anthropogenic combustion sources.

\subsection{Instrumental Absorption Efficiency $\alpha_{\text {API }}$}

For the whole record the EC concentration is comparable to the BC concentration. This indicates that as a first approximation the calibration of the optical apparatus with high-alpine 


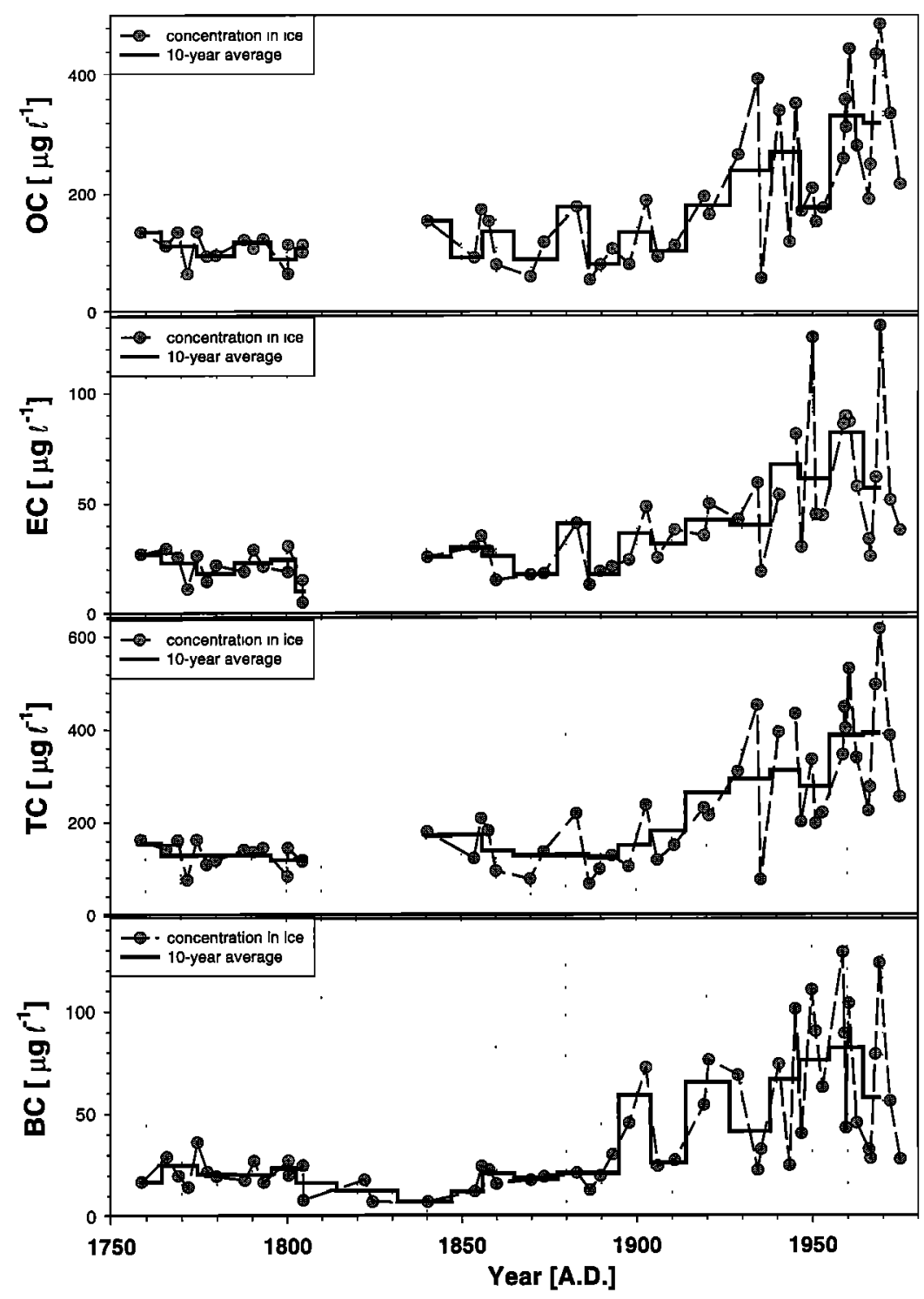

Figure 4. Ice core concentrations (dashed line) and 10-year averages (solid line) of organic carbon (OC), elemental carbon (EC), BC, and total carbon (TC) for the time period 1755 to 1975 . BC concentrations were calculated using $\alpha_{\text {API }}=9.3 \mathrm{~m}^{2} \mathrm{~g}^{-1}$.

aerosol is also adequate for snow samples. However, there are small differences in the records.

The difference might be due to an underestimation of the EC concentration resulting from catalytic oxidation of EC during the precombustion procedure. Metal oxides (e.g., Mn and $\mathrm{Fe}$ ) have been shown to act as soot oxidation catalysts under tight contact conditions [Lahaye et al., 1994; Neeft et al., 1996]. The mineral particles in our ice core samples contain significant amounts of metal oxides, such that a catalytic effect is conceivable. Lin and Friedlander [1988] showed that a similar catalytic effect reduced the oxidation temperature of EC during thermal analysis. However, we assume that the impact of this effect on our measurements is low since the trend of the $\mathrm{EC}$ record is in good agreement with that of the $\mathrm{BC}$ record $\left(R^{2}=0.81\right.$, see section 3.2.) and since both records show comparable concentrations.

Alternatively, individual values of $\alpha_{\text {API }}$ were calculated using the $\mathrm{ATN}_{\mathrm{BC}}$ and the EC measurements. Figure 6 shows that the resulting values of the 10-year averages vary between 2.1 and
$25.2 \mathrm{~m}^{2} \mathrm{~g}^{-1}$. Slightly lower values were found prior to the twentieth century. The mean value of $\alpha_{\text {API }}$ over the entire time period was $10.5 \pm 4.8 \mathrm{~m}^{2} \mathrm{~g}^{-1}$. This value is similar, to within the standard deviation, to measurements of high-alpine atmospheric aerosol.

Snow samples from the present, collected on the campus site of the University of Bern and at the high-alpine site Jungfraujoch (Switzerland, $3454 \mathrm{~m}$ asl), gave $\alpha_{\text {API }}$ values ranging between 5.1 and $9.7 \mathrm{~m}^{2} \mathrm{~g}^{-1}$ (open circles and open and solid diamonds in Figure 6). These values are comparable to the last 10-year average of the ice core $\left(10.2 \mathrm{~m}^{2} \mathrm{~g}^{-1}\right)$.

The relatively good agreement between atmospheric aerosol and snow samples is interesting, since in the former the carbonaceous aerosol particles are assumed to be coated with scattering material, while in the latter the water soluble fraction of scattering material is removed. For in situ measurements of aerosol particles this effect is thought to reduce $\alpha_{\text {AP }}$ [Liousse et al., 1993; Cachier and Pertuisot, 1994]. From the present results one might conclude that this effect is of minor 

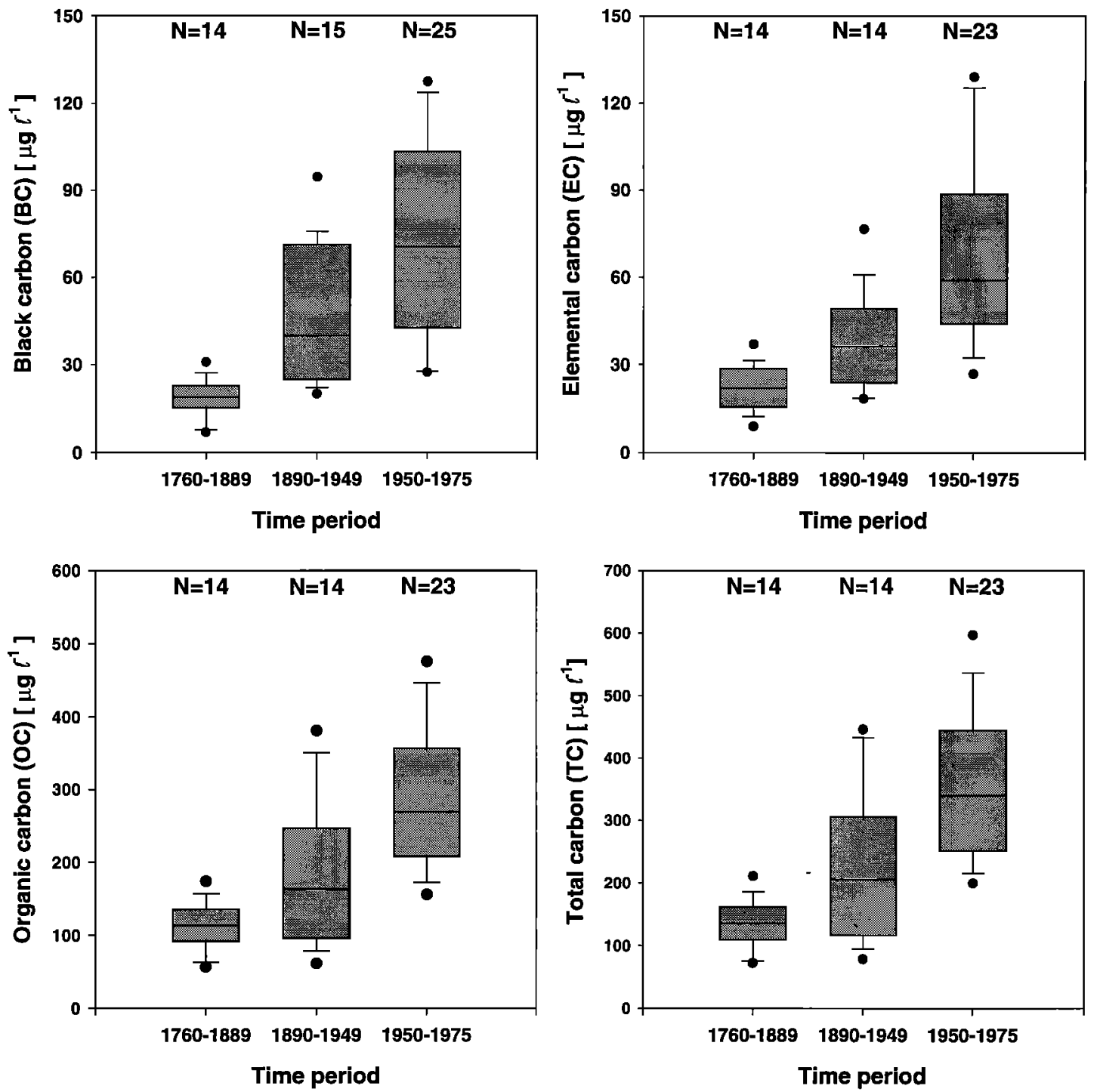

Figure 5. Box plots for three different time periods. The minimum and maximum as well as 95 th, 75 th, 50th, 25 th, and 5 th percentiles of BC, EC, OC, and TC concentrations are shown.

importance when using a quartz fiber filter with its inherent multiple scattering. Note that this is not necessarily true for other filter materials.

However, the calculated $\alpha_{\text {API }}$ shows a pronounced variability over the whole record (Figure 6). This finding was compared with data from the Greenland ice core EUROCORE, where $\alpha_{\text {API }}$ was reported to vary between 9 and $31 \mathrm{~m}^{2} \mathrm{~g}^{-1}$ [Cachier and Pertuisot, 1994]. A significant difference was found between ice samples from the first half of the twentieth century, with $\alpha_{\text {API }}$ values ranging between 18 and $25 \mathrm{~m}^{2} \mathrm{~g}^{-1}$, and older ice samples, with $\alpha_{\text {API }}$ values ranging between 8 and $12 \mathrm{~m}^{2} \mathrm{~g}^{-1}$. Cachier and Pertulsot [1994] presumed that this variability results from the fact that different combustion sources dominated; that is, coal combustion dominated in the first half of the twentieth century, and biomass burning dominated in the nineteenth century. Following this assumption, coal combustion might explain our high $\alpha_{\text {API }}$ values during the

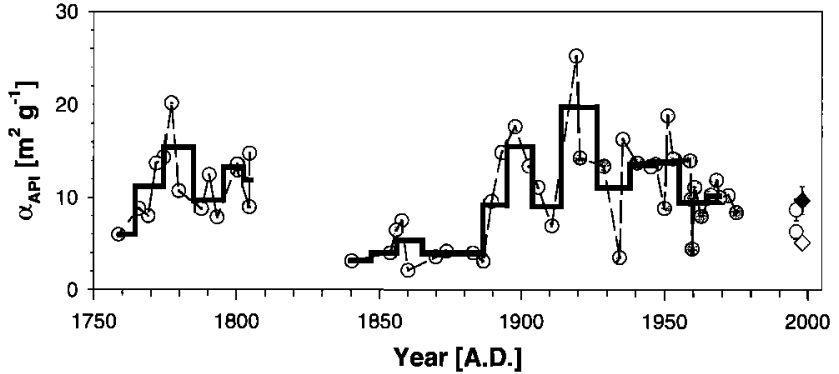

Figure 6. The calculated instrumental absorption efficiency $\alpha_{\mathrm{API}}$ of the ice core samples (dashed line and shaded circles) and of 10-year averages (solid line). In addition, $\alpha_{\text {API }}$ measured for snow samples of surface snow from Bern on November 14, 1995 (open circles), of surface snow from Jungfraujoch on February 20, 1998 (open diamond), and of snow in 10-cm depth from Jungfraujoch on February 20, 1998 (solid diamond) are shown. 
first half of the twentieth century. Note that all these values are given for $\alpha_{\mathrm{API}}$, and no corrections are made so far for possible enhancements due to multiple scattering in fibrous filters as described by Bodhaine [1995].

\subsection{Comparison of Carbon Concentration and Estimated Emissions}

We compared our ice core measurements with estimated BC and TC emissions from different European countries. The aim was to test to what extent our particulate carbon records represent the emissions from European countries.

Combustion of coal, wood, and petroleum products were the main sources of $\mathrm{BC}$ and $\mathrm{TC}$ in western Europe during the investigated period. Their relative contribution to the total emission changed with time. For Switzerland, wood combustion $(87 \%)$ was the main type of energy production in 1850 [Bergier, 1978; Marek, 1992] and was therefore the main source of carbonaceous particles. Coal became the most important combustion fuel $(80 \%)$ at the end of the nineteenth century and continued to be until petroleum products gained in importance after the Second World War [Marek, 1992; Bundesamt für Energiewirtschaft (BEW), 1987]. Presently, fossil fuel combustion accounts for over $99 \%$ of the emitted BC in western Europe [Cooke and Wilson, 1996]. In contrast, biomass burning, an important source in boreal latitudes and the tropics, is of lower importance in Europe during modern times [Liousse et al., 1996].

Because of the short residence time of carbonaceous particles in the atmosphere, we restricted our study to the countries surrounding the ice core site, that is, Switzerland, Italy, France, and Germany, and to the main sources. As sources, hard coal, brown coal, and petroleum products, that is, diesel oil, motor gasoline, jet fuel, kerosene, and heavy fuel oil were considered. Wood combustion was not included, despite the importance of this source before 1900 , because of lack of data.

The annual databases used [Mitchell, 1992; Marek, 1992; $B E W, 1987]$ cover continuous production and trade data for the time period from 1820 to 1985 for coal and from 1860 to 1985 for petroleum. Detailed consumption statistics were not available, and therefore fuel consumption was calculated as production plus import minus export.

The calculated fuel consumption data were converted into $\mathrm{BC}$ and $\mathrm{TC}$ emissions using emission factors (EF) and carbon densities presented in Table 1. EFs of TC were calculated from the sum of the BC and OC emission factors. The applied EFs are means for industrial and domestic use and for developed and developing countries [Cachier, 1998]. They take into account that domestic fuel combustion is less efficient than industrial fuel combustion [Cooke and Wilson, 1996]. No information was available about the reduction of EFs through air pollution control systems and the evolution in combustion techniques. Hence EFs were assumed to be constant over the last 200 years.

The EFs of different petroleum products vary significantly [Cachier, 1998], and hence knowledge of the relative usage of different petroleum products is needed. Since this information was not available, we based their relative consumption on the European production rates for 1970 [Department of International Economic and Social Affairs, 1983] and assumed them to be constant over the investigated period. The other products were assumed to have a small EF and were therefore considered to behave similarly to heavy fuel oil (Table 1). Because of
Table 1. Relative Use of the Petroleum Products in 1970 in Europe and Emission Factors for TC and BC and Carbon Density of Each Fuel

\begin{tabular}{|c|c|c|c|c|}
\hline & \multirow{2}{*}{$\begin{array}{c}\text { Relative Use } \\
\text { of Petroleum } \\
\text { Products, }{ }^{a} \\
\%\end{array}$} & \multicolumn{2}{|c|}{$\begin{array}{c}\text { EF, g } \\
(\mathrm{kg} \mathrm{C}, \text { Fuel })^{-1}\end{array}$} & \multirow{2}{*}{$\begin{array}{c}\text { Carbon } \\
\text { Density } \\
\text { (Fuel), } \\
\mathrm{kg} \mathrm{C} \mathrm{kg}^{-1}\end{array}$} \\
\hline & & $\mathbf{T C}^{\mathrm{h}}$ & $\mathrm{BC}^{\mathrm{c}}$ & \\
\hline \multicolumn{5}{|l|}{ Petroleum products } \\
\hline Diesel & 27 & 10 & 5 & $0.9^{\mathrm{d}}$ \\
\hline Motor gasoline & 14 & 0.5 & 0.1 & $0.9^{d}$ \\
\hline Kerosene & 2 & 1.5 & 0.3 & $0.9^{d}$ \\
\hline $\begin{array}{l}\text { Jet fuels and aviation } \\
\text { gasoline }\end{array}$ & 2 & 2 & 1 & $0.9^{\mathrm{d}}$ \\
\hline Heavy fuel oil & 54 & 0.1 & 0.02 & $0.9^{\mathrm{d}}$ \\
\hline Hard coal & & 6 & 3 & $0.915^{\mathrm{d}}$ \\
\hline Brown coal (lignite) & & 19 & 4 & $0.315^{\mathrm{e}}$ \\
\hline
\end{tabular}

${ }^{a}$ Values are for European production 1970 [Department of Internatoonal Economic and Social Affairs, 1983].

'Source is Cachier [1998]: This is the sum of EF for OC and BC; values are adapted from Cachier [1995], Liousse et al. [1996], and Cooke and Wilson [1996].

${ }^{\circ}$ Cachier [1998]: Values are adapted from Cachier [1995], Liousse et al. [1996], and Cooke and Wilson [1996].

Roempp et al. [1997].

'Roempp et al. [1997]: A water content of $45 \%$ and $70 \%$ carbon content of the dry brown coal is assumed.

Abbreviations are as follows: EF, emission factors; TC, total carbon; and $\mathrm{BC}$, black carbon.

the high EF and its widespread use, diesel oil dominates the production of $\mathrm{BC}$ and $\mathrm{TC}$ from petroleum products.

Hard coal and petroleum products were assumed to consist of $91.5 \%$ and $90 \%$ carbon, respectively [Roempp et al., 1997]. For the brown coal we assumed a water content of about $55 \%$ [Roempp et al., 1997] and a carbon content of $70 \%$ of the dried brown coal [Roempp et al., 1997], resulting in a carbon density of $31.5 \%$.

Table 2 lists the 10 -year averages of the estimated BC (Table 2a) and TC (Table 2b) emissions from Switzerland, France, Italy, Germany and of the sum of these countries (labeled "All Countries"). Table 2 includes the emissions of the different fuel sources for each country. Today the use of petroleum products dominates BC and TC emissions in Switzerland and Italy, whereas in Germany coal combustion is the most important source of $\mathrm{BC}$ and $\mathrm{TC}$. The total emissions of all countries are dominated by the emissions from Germany and hence are dominated by coal combustion. In 1985, coal consumption accounted for $70 \%$ of the total BC emissions. In the inventory of Penner et al. [1993], which includes wood and biomass burning, coal use accounted for $60 \%$ of the $\mathrm{BC}$ emissions in western Europe.

For 1985 we estimated a total $\mathrm{BC}$ emission of $1.34 \mathrm{Tg}$. This value is of the same order of magnitude as the studies of Cooke and Wilson [1996] and Penner et al. [1993] for western Europe, where estimated BC emissions were $1.09 \mathrm{Tg} \mathrm{yr}^{-1}$ (for 1984) and $0.59 \mathrm{Tg} \mathrm{yr}^{-1}$ (for 1980), respectively. Our value does not include emissions of the other western European countries and does not consider biomass burning and wood combustion. Including emissions from the remaining western European countries and adding the omitted sources, our value would be higher, indicating that emission estimates are of the right order of magnitude but need further refinement.

Figure 7 shows the record of the 10-year means of the estimated $\mathrm{BC}$ emissions for the sum of all countries surrounding the drilling site and the EC ice core records. A similar 

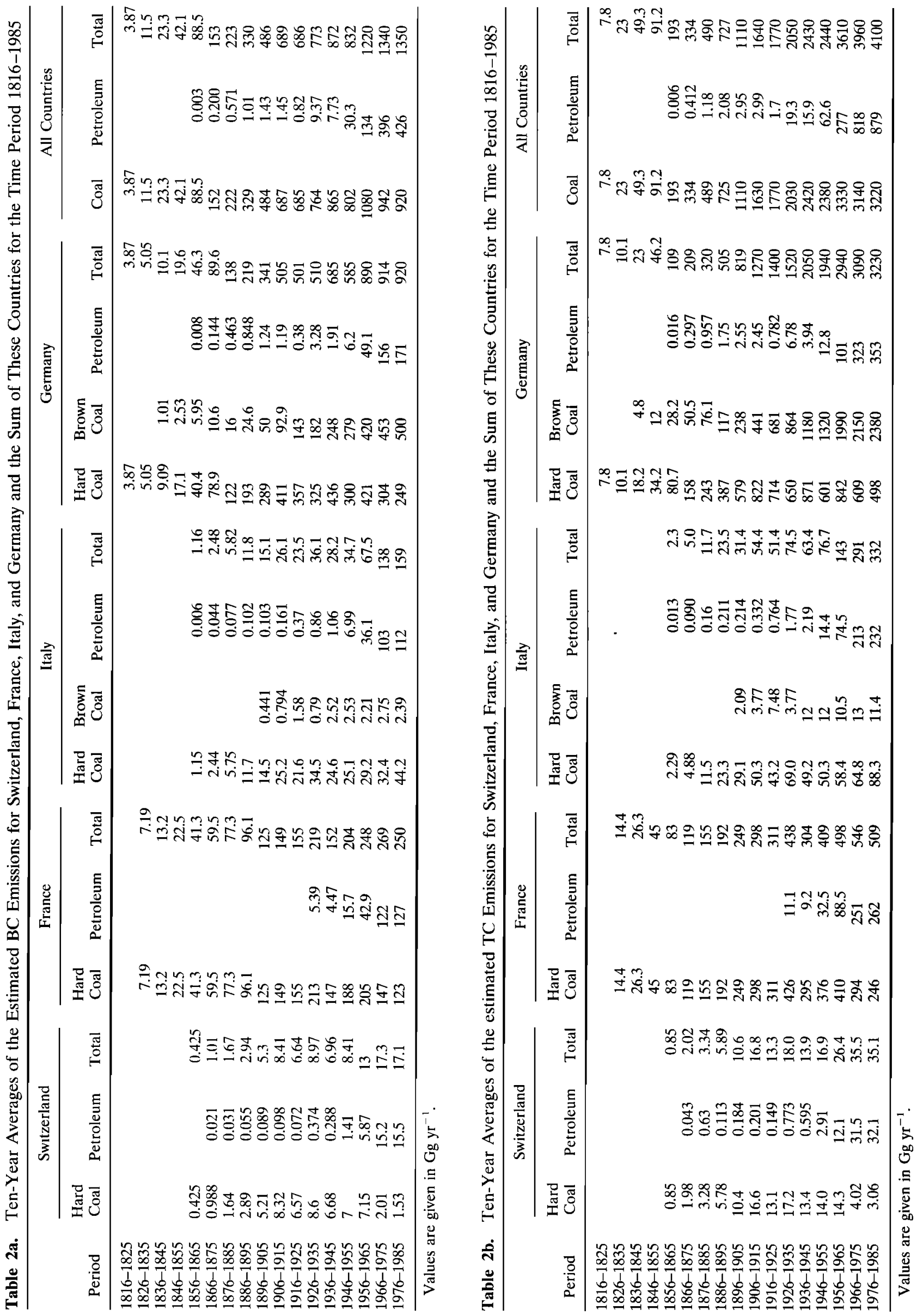
increase starting in 1880 is attributed to enhanced fossil fuel combustion. The good correlation between 1880 and 1975 $\left(R^{2}=0.56\right)$ indicates that the ice core, indeed, reflects the carbonaceous aerosol emissions of western Europe, which is consistent with the corresponding sulfate record [Schwikowski et al., 1999]. Therefore the ice core record might be used to derive the level of emissions for the time period where no emission data are available. Before 1890 the measured EC concentrations are at a constant level, indicating that between 1755 and 1890 particulate carbon was emitted at a more or less constant rate. Wood combustion is believed to be the main source for that time period [Marek, 1992].

Table 3 gives correlation coefficients between $\mathrm{BC}$ emissions and the $\mathrm{BC}$ record and between $\mathrm{TC}$ emissions and the TC record. The correlation coefficients increase in the sequence $\mathrm{BC}, \mathrm{EC}$, and TC. We believe that the differences in the correlation coefficients result from the accuracy of the analyses. As discussed in section 2.2, the measurements of both EC and $\mathrm{BC}$ include possible systematic errors, whereas systematic errors can be neglected for TC measurements.

The high correlation between OC and EC is at first astonishing, considering that $\mathrm{OC}$ includes both primary and secondary $\mathrm{OC}$ and that the correlation between EC and secondary OC should be lower because of other sources of secondary OC. From the good correlation one may hypothesize that a large fraction of secondary OC is water soluble, which is removed during the filtration step. This hypothesis is corroborated by the good correlation (Table 3) between primarily emitted TC and TC measured in the ice core.

\section{Conclusions}

We presented historical records of $\mathrm{BC}, \mathrm{EC}, \mathrm{OC}$, and TC concentrations covering the time period 1755-1975. They were obtained by analysis of ice core samples from a European high-alpine glacier using an optical and a thermal method. Concentrations varied between 7 and $128 \mu \mathrm{g} \mathrm{L}^{-1}$ for $\mathrm{BC}$, between 5 and $130 \mu \mathrm{g} \mathrm{L}^{-1}$ for EC, between 53 and $484 \mu \mathrm{g} \mathrm{L}^{-1}$ for OC, and between 66 and $614 \mu \mathrm{g} \mathrm{L}^{-1}$ for TC.

Throughout the record, short-time concentration fluctuations by 1 order of magnitude occurred for all species and were attributed to the seasonal variations as a result of enhanced

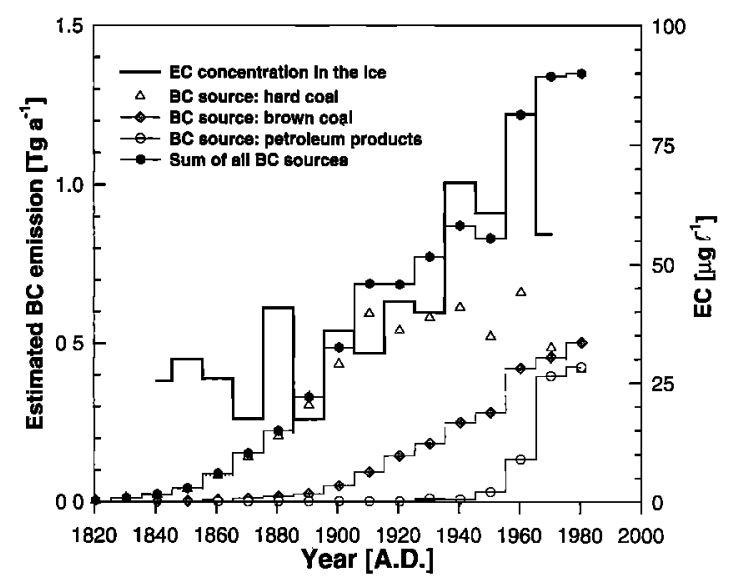

Figure 7. EC concentrations (10-year averages) for 1820 to 1975 and the sum of estimated BC emissions of Switzerland, France, Italy, and Germany. Hard coal, brown coal, and petroleum products are included as sources.
Table 3. Correlation Coefficient $R^{2}$ of the Correlations Between $\mathrm{BC}$ and $\mathrm{EC}$ Concentrations in the Ice and the Estimated BC Emissions and Between the TC and the Estimated TC Emissions for the Time Period 1880 to 1975

\begin{tabular}{ccc}
\hline $\begin{array}{c}\text { Ice } \\
\text { Records }\end{array}$ & $\begin{array}{c}\text { Estimated BC } \\
\text { Emissions }\end{array}$ & $\begin{array}{c}\text { Estimated TC } \\
\text { Emissions }\end{array}$ \\
\hline BC & 0.46 & \\
EC & 0.56 & 0.93 \\
TC & & 0.93 \\
\hline
\end{tabular}

vertical transport of air from the PBL in summer. An increase in concentrations was observed superimposed on the fluctuations. From preindustrialization $(1755-1890)$ to modern times (1950-1975), BC, EC, OC, and TC concentrations increased by factors of 3.7, 3.0, 2.5, and 2.6, respectively.

The sum of the estimated BC emissions of Germany, France, Switzerland, and Italy calculated from fossil fuel consumption was shown to correlate $\left(R^{2}=0.56\right)$ with the record of EC concentrations for the time of enhanced fossil fuel use, that is, 1890-1975. This observation provides evidence that the presented EC record reflects the particulate carbon emissions of western Europe. Hence, for time periods without emission data, the level of emissions might be deduced from this record.

Compared to the Greenland EUROCORE ice core records [Cachier and Pertuisot, 1994], the presented EC and TC concentrations are higher by a factor of about 10-20. This difference in concentration is attributed to the proximity of the Colle Gnifetti ice core to the combustion sources.

The trends of EC and BC concentration records show the expected good agreement $\left(R^{2}=0.81\right)$. Furthermore, the concentrations are fairly comparable, indicating that the instrumental calibration factor $\alpha_{\text {API }}$ of the optical apparatus was representative of these ice samples when calibrated with atmospheric aerosol. Using the attenuation and EC data, a calibration yielded a mean value $\alpha_{\mathrm{API}}=10.5 \mathrm{~m}^{2} \mathrm{~g}^{-1}$, which agrees with $\alpha_{\mathrm{API}}$ of present-day snow samples and the calibration value $\left(\alpha_{\text {API }}=9.3 \mathrm{~m}^{2} \mathrm{~g}^{-1}\right)$.

Furthermore, attenuation measurements showed that absorption due to mineral particles varied between 2 and $30 \%$. No significant increase was observed, suggesting that particulate carbon and mineral particles have different sources.

Acknowledgments. The authors thank Thomas Doring and Leonhard Tobler for their highly valuable help in the sample preparation.

\section{References}

Baltensperger, U., H. W. Gäggeler, D. T. Jost, M. Lugauer, M. Schwikowski, E. Weingartner, and P. Seibert, Aerosol climatology at the high-alpine site Jungfraujoch, Switzerland, J. Geophys. Res., 102, 19,707-19,715, 1997.

Bergier, J. F., Wachstum, Energie, Verkehr vor der industriellen Revolution im Raume der heutigen Schweiz und der Zentralalpen (in German), in Wirtschaftliches Wachstum, Energie und Verkehr vom Mittelalter bis ins 19. Jahrhundert, edited by H. Kellenbenz, pp. 1528, Fischer, Stuttgart, Germany, 1978.

Bodhaine, B. A., Aerosol absorption measurements at Barrow, Mauna Loa and the South Pole, J. Geophys. Res., 100, 8967-8975, 1995.

Bundesamt für Energiewirtschaft (BEW), (in German and French), Energlestatistik der Schweiz 1910-1985, Verband Schweiz. Elektr., Aarau, Switzerland, 1987.

Cachier, H., Combustion of carbonaceous aerosols in the atmosphere: Implications for ice core studies, in Ice Core Studies of Global Bio- 
chemical Cycles, edited by R. Delmas, NATO ASI Ser., Ser. I, 30, 313-346, 1995.

Cachier, H., Carbonaceous combustıon aerosols, in Atmospheric Particles, edited by R. M. Harrison and R. van Grieken, pp. 295-348, John Wiley, New York, 1998.

Cachier, H., and M. H. Pertuisot, Particulate carbon in arctic ice, Analusis, 22, M34-M37, 1994.

Cachier, H., M. P. Bremond, and P. Buat-Ménard, Determination of atmospheric soot carbon with a simple thermal method, Tellus Ser. $B, 41 B, 379-390,1989$.

Chýlek, P., and V. Srivastava, Aerosol and graphitic carbon content of snow, J. Geophys. Res., 92, 9801-9809, 1987.

Chýlek, P., B. Johnson, and $\mathrm{H}$. Wu, Black carbon concentration in a Greenland Dye-3 ice core, Geophys. Res. Lett., 19, 1951-1953, 1992.

Cooke, W. F., and J. J. N. Wilson, A global black carbon aerosol model, J. Geophys. Res., 101, 19,395-19,409, 1996.

Countess, R. J., Interlaboratory analyses of carbonaceous aerosol samples, Aerosol Sci. Technol., 12, 114-121, 1990.

Department of International Economic and Social Affairs, Yearbook of World Energy Statstics 1981, Stat. Off., United Nations, New York, 1983.

Dóring, T., Rekonstruktion der atmosphärischen Kupfer-, Zink- und Bleigehalte und der Bleiisotopen-Zusammensetzung an einem hoch-alpinen Eisbohrkern unter Anwendung der ICP-MS Technik (in German), Ph.D. thesis, Univ. of Bern, Bern, 1999.

Dóscher, A., H. W. Gággeler, U. Schotterer, and M. Schwikowski, A 130 years deposition record of sulfate, nitrate and chloride from a high-alpine glacier, Water Air Soil Pollut., 85, 603-609, 1995.

Döscher, A., H. W. Gäggeler, U. Schotterer, and M. Schwikowski, A historical record of ammonium concentrations from a glacier in the Alps, Geophys. Res. Lett., 23, 2741-2744, 1996.

Haeberli, W., U. Schotterer, D. Wagenbach, H. Haeberli-Schwitter, and S. Bortenschlager, Accumulation characteristics on a cold, highalpine firn saddle from a snow-pit study on Colle Gnifetti, Monte Rosa, Swiss Alps, J. Glaciol., 29, 260-271, 1983.

Hammer, C., P. A. Mayewski, D. Peel, and M. Stuiver, Preface, $J$. Geophys. Res., 102, 26,315-26,316, 1997.

Hansen, A. D. A., H. Rosen, and T. Novakov, The Aethalometer - An instrument for the real-tıme measurement of optical absorptıon by aerosol particles. Sci. Total Environ., 36, 191-196, 1984.

Hansen, A. D. A., V. N. Kapustin, V. M. Kopeikin, D. A. Gıllette, and B. A. Bodhaine, Optical absorption by aerosol black carbon and dust in a desert region of central Asia, Atmos. Environ., Part A, 27A, 2527-2531, 1993.

Intergovernmental Panel on Climate Change, Climate Change 1994, edited by J. T. Houghton et al., Cambridge Univ. Press, New York, 1995.

Lahaye, J., S. Boehme, and P. Ehrburger, Metallic additives in soot formation and post-oxidation, in Soot Formation in Combustion, edited by H. Bockhorn, pp. 307-315, Springer-Verlag, New York, 1994.

Lavanchy, V. M. H., H. W. Gaggeler, S. Nyeki, and U. Baltensperger, Elemental carbon (EC) and black carbon (BC) measurements with a thermal method and an aethalometer at the high-alpine research station Jungfraujoch, Atmos. Environ., 33, 2759-2769, 1999.

Lin, C. and S. K. Friedlander, A note on the use of glass fiber filters in the thermal analysis of carbon containing aerosols, Atmos. Environ., 22, 605-607, 1988 .

Liousse, C., H. Cachier, and S. G. Jennings, Optical and thermal measurements of black carbon aerosol content in different environments: Variation of the specific attenuation cross-section, sigma $(\sigma)$, Atmos. Environ., Part A, 27A, 1203-1211, 1993.

Liousse, C., J. E. Penner, C. Chuang, J. J. Walton, H. Eddelman, and $\mathrm{H}$. Cachier, A global three-dimensional model study of carbonaceous aerosols. J. Geophys. Res., 101, 19,411-19,432, 1996.

Lugauer, M., U. Baltensperger, M. Furger, H. W. Gaggeler, D. T. Jost, M. Schwikowski, and H. Wanner, Aerosol transport to the high alpine sites Jungfraujoch $(3454 \mathrm{~m})$ and Colle Gnifetti $(4453 \mathrm{~m})$, Tellus Ser. B, 50B, 76-92, 1998.

Marek, D., Kohle: Die Industrialisierung der Schweiz aus der Energieperspektive 1850-1900, (in German), Ph.D. thesis, Univ. of Bern, Bern, 1992.

Maupetit, F., and R. J. Delmas, Snow chemistry of high altitude glaciers in the French Alps, Tellus Ser. B, 46B, 304-324, 1994.
Maupetit, F., D. Wagenbach, P. Weddeling, and R. J. Delmas, Seasonal fluxes of major ions to a high altitude cold Alpine Glacier, Atmos. Environ., 29, 1-9, 1995.

Mitchell, B. R., International Historical Statistics: Europe 1750-1988, Stockton, New York, 1992.

Neeft, J. P. A., M. Makkee, and J. A. Moulijn, Catalysts for the oxidation of soot from diesel exhaust gases, I, An exploratory study, Appl. Catal. B, 8, 57-78, 1996.

Oeschger, H., U. Schotterer, B. Stauffer, W. Haeberli, and H. Rothlisberger, First results from alpine core drilling projects, $Z$. Gletscherkd. Glazialgeol., 13, 193-208, 1977.

Ogren, J. A., and R. J. Charlson, Elemental carbon in the atmosphere: Cycle and lifetime, Tellus Ser. B, 35B, 241-254, 1983.

Penner, J. E., and T. Novakov, Carbonaceous particles in the atmosphere: A historical perspective to the Fifth International Conference on Carbonaceous Particles in the Atmosphere, J. Geophys. Res. 101, 19,373-19,378, 1996.

Penner, J. E., H. Eddleman, and T. Novakov, Towards the development of a global inventory for black carbon emission, Atmos. Environ. Part A, 27A, 1277-1295, 1993.

Petzold, A., and R. Niessner, Method comparison study on sootselective techniques. Mikrochim. Acta, 117, 215-237, 1995.

Petzold, A., C. Kopp, and R. Niessner, The dependence of the specific attenuation cross-section on black carbon mass fraction and particle size, Atmos. Environ. 31, 661-672, 1997.

Pinnick, R. G., G. Fernandez, E. Martinez-Andazola, B. D. Hinds, A. D. A. Hansen, and K. Fuller, Aerosol in the arid southwestern United States: Measurements of mass loading, volatility, size distribution, absorption characteristics, black carbon content, and vertical structure to $7 \mathrm{~km}$ above sea level, J. Geophys. Res., 98, 2651-2666, 1993.

Roempp, H., H. Hulpke, H. A. Koch, and R. Wagner, CD Römpp Chemie Lexikon $A-Z$, version 1.4, [CD-ROM], Georg Thieme, Stuttgart, Germany, 1997.

Schotterer, U., H. Oeschger, D. Wagenbach, and K. O. Münnich, Information on paleo-precipitation on a high-altitude glacier Monte-Rosa, Switzerland, Z. Gletscherkd. Glazialgeol., 21, 379-388, 1985. Schütz, L., Atmospheric mineral dust - Properties and source markers, in Paleoclimatology and Paleometeorolgy: Modern and Past Patterns of Global Atmospheric Transport, NATO ASI Ser. C, vol. 282, edited by M. Leinen and M. Sarnthein, pp.359-383, Kluwer Acad., Norwell, Mass., 1989.

Schwikowski, M., A. Döscher, H. W. Gäggeler, and U. Schotterer, Anthropogenic versus natural sources of atmospheric sulfate derived from an Alpine ice core, Tellus Ser. B, in press, 1999.

Tomadin, A., G. Cesari, S. Fuzzi, V. Landuzzi, R. Lenaz, A. Lobietti, P. Mandrioli, M. Mariotti, A. Mazzucotelli, and R. Vannucci, Eolian dust collected in springtime (1979 and 1984 years) at the seawaterair interface of the Northern Red Sea, in Paleoclimatology and Paleometeorology: Modern and Past Patterns of Global Atmospheric Transport, NATO ASI Ser. C, vol. 282, edited by M. Leinen and M. Sarnthein, pp. 267-282, Kluwer Acad., Norwell, Mass., 1989.

Wagenbach, D., Environmental records in Alpine glaciers, in The Environmental Record in Glacter and Ice Sheets, edited by H. Oeschger and C. C. Langway Jr., pp. 69-83, John Wiley, New York, 1989.

Wagenbach, D., S. Preunkert, J. Schafer, W. Jung, and L. Tomadin, Northward transport of Saharan dust recorded in a deep Alpine ice core, in The Impact of Desert Dust Across Mediterranean, edited by S. Guerzoni and R. Chester, pp. 291-300, Kluwer Acad., Norwell, Mass., 1996.

U. Baltensperger, U. Schotterer, and M. Schwikowski, Paul Scherrer Institute, CH-5232 Villigen PSI, Switzerland. (baltensperger@psi.ch; schotterer@climate.unibe.ch; schwikowski@psi.ch)

H. W. Gággeler and V. M. H. Lavanchy, Department of Chemistry and Biochemistry, University of Bern, CH-3012 Bern, Switzerland. (gaeggeler@psi.ch; vincent.lavanchy@iac.unibe.ch)

(Received February 19, 1999; revised June 3, 1999; accepted June 7, 1999.) 